\title{
JK 膜を使用した肘関節形成術の長期成績
}

(第 1 報）

$\begin{array}{cccccc}\text { 九大整形外科 } & & & & & \\ \text { 緒 万 } & \text { 公 } & \text { 介・喜 } & \text { 多 } & \text { 正 } & \text { 鎮 } \\ \text { 野 副 } & & \text { 勝・近 } & \text { 藤 } & \text { 正 } & \text { 一 } \\ \text { 市ヶ谷 } & \text { 学 } & & & \end{array}$

\section{Long-term Prognosis of Chromicized Fascial Arthroplasty of The Elbow}

By

\author{
K. Ogata, M. Kita, M. Nozoe, M. Kondo \& M. Ichigaya. \\ Department of Orthopedic Surgery, Kyushu \\ University School of Medicine.
}

The authors have evaluated the late results in 22 patients on whom arthroplasty of the elbow using the J-K Membrane had been performed during the year 1950 to 1969 .

An average of 14 years following operation, these patients had an average range of motion of 53 degrees with good stability and muscle strength. The end results among the group of patients whose ankylosis followed an infective arthritis were inferior to those among the group in rhematoid arthritis and trauma. Excellent results have been obtained among the patients who had undergone arthroplasty within a few years after the onset of ankylosis.

The functional results, with few exceptions, showed little change after the first year following operation. Roentgenographycally, there was hypertrophy of the coronoid process in many instances.

\section{はじめに}

この数年来, 人工関節の使用経験が数多く報告され ，材料の改良や手術手技の向上に伴ってその成績も進 歩してきている．他方，生筋膜や皮虐等を用いた従来 の関節形成術も異物を用いないため，人工関節の欠点 を埋める方法として放棄できない，今回われわれは， 九大整形外科において，昭和 25 年から 44 年にわたり 行われた，主として J K 膜を使用した肘関節形成術の 予後を追跡調査し，その長期成績を判定したので報告 する。

\section{症例}

症例は 57 例で，原因疾患別では，外傷 30 例，リウ マチ 7 例, 感染性関節炎 14 例, その他 6 例である. 追跡調查できた症例は 22 例で, 外傷 10 例, リウマチ
5 例，その他の関節炎 7 例である.

$$
\text { 手術方法 }
$$

後方弓状切開にて肘頭端を切離し関節を開く. 上腕 尺側顆部の尺骨神経を確認し，てれを周囲より剥離 してテープをかけて保護する．旧関節裂隙部の切除 を行うが, 骨切除範囲は, 術後の動摇関節を防ぐため に運動障害になる部分を必要最小限切除するにとどめ る. 用意した J K 膜で上腕骨下端を包み肘頭端を元に 戻す. 術後 3 週より屈伸器による運動練習を行う.

$$
\text { 成綪 (表1) }
$$

外傷によるもの 10 例の術後平均 18 年の可動域は 62 度であった。受傷から 手術までの期間は平均 4 年 で，乙の期間が短いものほど可動域の改善は良好であ った. 図 1 の症例は 51 才の男性で，35才の時上腕骨 
表 1 原因疾患別の術後平均可動域

\begin{tabular}{|c|c|c|c|c|c|c|c|}
\hline 原 因 疾 患 & 症 例 数 & $\begin{array}{l}\text { 発病から } \\
\text { 手術まで }\end{array}$ & $\begin{array}{l}\text { 手術時の } \\
\text { 年 令 }\end{array}$ & $\begin{array}{l}\text { 術前 の } \\
\text { 可動 域 }\end{array}$ & $\begin{array}{l}\text { 退 院 時 } \\
\text { 可動 域 }\end{array}$ & $\begin{array}{l}\text { 調 查 時 } \\
\text { 可動 域 }\end{array}$ & 術後年数 \\
\hline $\begin{array}{l}\text { 骨折・脱臼骨折 } \\
\text { リウ文 } \\
\text { その他の關節炎 }\end{array}$ & $\begin{array}{r}10 \\
5 \\
7\end{array}$ & $\begin{array}{l}\text { 4. 3年 } \\
\text { 16年 }\end{array}$ & $\begin{array}{l}30 \\
24 \\
29\end{array}$ & $\begin{array}{r}11^{\circ} \\
18^{\circ} \\
0^{\circ}\end{array}$ & $\begin{array}{l}64^{\circ} \\
87^{\circ} \\
48^{\circ}\end{array}$ & $\begin{array}{l}62^{\circ} \\
70^{\circ} \\
33^{\circ}\end{array}$ & $\begin{array}{r}18 \\
6 \\
15\end{array}$ \\
\hline （総平均）計 & 22 & & 28 & $9^{\circ}$ & $64^{\circ}$ & $53^{\circ}$ & 14 \\
\hline
\end{tabular}

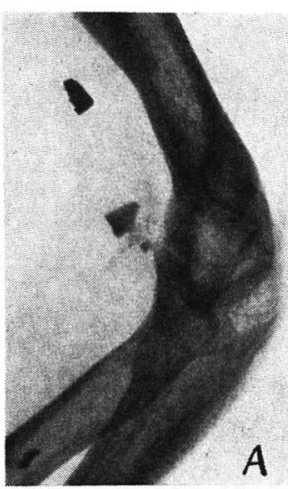

A. 術 前

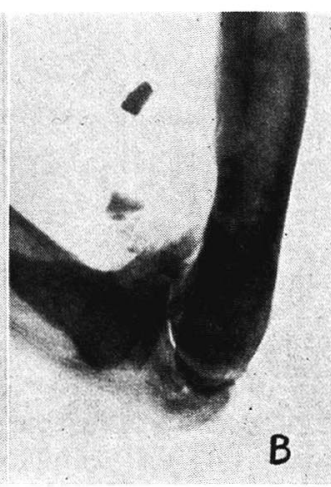

B. 術後16年
図 1

（时関節の前上方に見える陰影は戦争中に受 けた弾丸の断片)

開放骨折をおこし 1 年後約 80 度に強值（図1-A). 肘関節形成術後 16 年の現在, 85 度の可動域を得てい る. 前腕の回施はできないが，日常生活に支障なく満 足な結果が得られている（図1-B). リウマチによ るもの 5 例の術後平均 6 年の可動域は 70 度で, 全症 例に回施運動の改善か認められる，その他の関節炎に よるもの 7 例では，発病から手術までの期間が長く， 平均 16 年である. 術後平均 15 年の可動域は 33 度で, 特に結核によるものは, 再発例, 再強直例を認め成續 が悪い，全症例の平均 14 年後の 可動域を平均すると 53 度である。疾患別では，リウマチによるものが最 も良好で，外傷例がそれにつぎ，その他の関節炎によ るものが最も劣っている. 成績不良の原因としては, 発病から手術までの期間が長く，その間に上肢の筋力 が低下し，術後十分な運動練習ができなかったことが 考学られる. 退院時との成績を比較すると, 外傷例で はほとんど変化していないが，リウマチでは 6 年後に 17 度，その他の 関節炎例では 15 年後に 15 度の 平均 可動域減少を認める.

レ線所見では，再強直例を除けば 約 $60 \%$ の症例に

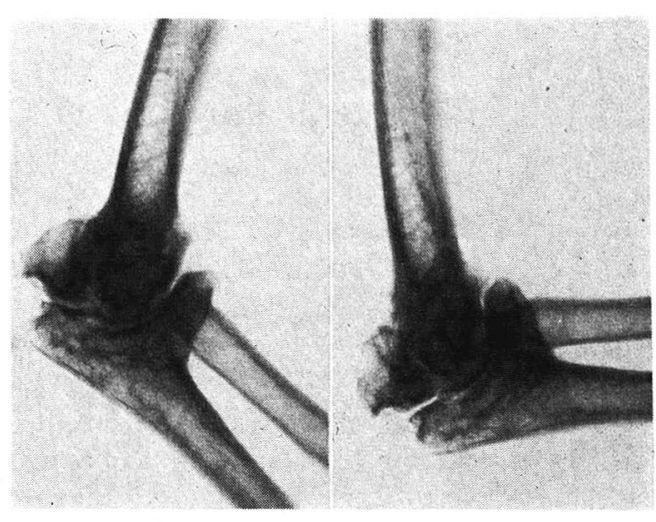

図 2 右时関節形成術後 23年

鳥口突起端の延長がみられ，巨大な鳥口突起を持つも のや，烏口突起端に遊離新生骨を持つものなどが認め られた. 又时頭に仮関節を残しながら機能上全く問題 のない症例もみられた（図2）。

\section{合併症}

術後合併症では，結核の再然をみた 1 例のはか化感 染を起こしたものはない. 57 例中 9 例に，入院中尺 骨神経麻瘦の合併がみられるが, 退院時には全例回復 している. 調查時, 関節内雑音を示すものが約 $40 \%$, 重い物を持った時に軽い疼痛を訴えるものが約 $30 \%$ にみられたが，日常生活に支障はない，動摇関節を示 したものや，握力が著明に低下したものはなかった。

\section{考察}

$\mathrm{J}$ K膜は自家筋膜をクローム化したもので，軽度の 刺激作用により正常関節腔に近い液腔を生ずると言わ れている，神中は，61例の予後を調査し，平均術後 9 年において, 63 度の可動域を得ている. 今回われ われの行った平均 14 年後の調査では, 53 度と大差な く, 炎症例が, 外傷例に比べて劣る点も同様の傾向を みるととができた。 
永山ら（1.971）は, 主として大腿生筋膜を用いた関 節形成術を行い良好な結果を得ている. 永山らによれ ば, 術後の可動域の獲得は最終的な成績の優劣にかか わりなく, 大体術後 6 力月より 8 力月の間に得られる としているが, われわれの症例では, 術後約 3 力月か ら 6 力月の運動練習後にほぼ最大運動範囲が得られて いる. 長期成績において, 退院時の可動域よりも著し く増大していた症例はみられなかった。

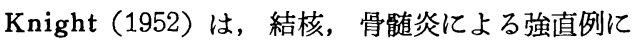
対しては, 関節形成術の適応はないとしているが，わ れわれの症例でこのような例に行ったものは，外傷 例, リウマチ例に比べ, 渚しく成績が悪い，乙れは主 に筋力低下により術後の運動練習が充分行えなかった ためではないかと思われる。

Dee (1972)はリウマチによる強㨁に対する関節形成 術は, 安定性と可動性にわいて必ずしも良好な結果が 期待できないと考光，人工関節による置換を勧めてい る.われわれの行ったリウマチ例では, 動摆関節を示す ものは一例もなく, 可動性についても良好な結果が得 られている. 七川(1969)もりウマチに対し主として皮 膚を用いた関節形成術を行い良好な成績を得ている.

最近, 人工関節の使用経験が数多く報告され，その 成績も進歩してきている。しかし人工関節は，生体内 に大きな異物を插入するてとであって様々な合併症に 十分な配虑をはらわねばならない. 特に人工関節の脚 部の不安定性 (sinking), 耐久性などの問題が今後に 残されている．乙の点，」K膜による関節形成術は， 人工関節の欠点を埋める方法として放棄できない。特 に时関節の場合は, 長期間安定した成績が得られてお り，現在なお有用な手術法と考えられる.

\section{結}

\section{語}

（1） J K 膜を使用した 时関節形成術 22 例の術後 平均 14 年の可動域は平均 53 度で, 動摇関節を示した ものや筋力が著明に低下したものはなかった。

（2）原因疾患別では, リウマチ, 外傷例に対して 感染性関節炎によるものの成績が劣っていた. 又, 発 病から手術までの期間が短いものほど成績は良好であ った.

（3）術後長期レ線所見で, 鳥口突起端の延長を見 るものが多かった。

（4）J K膜を使用する肘関節形成術は，長期間安 定した成績が得られており, 人工関節が用いられるよ うになってきた現在な㧍，有用な手術法と考えられる。

$$
\text { 文献 }
$$

1) Campbell, W. C.: J. Bone Joint Surg., 13, 223, 1931.
2) Knight, R. A. et al.: J. Bone Joint Surg., 34-A, 610, 1952.

3) Barr, J. S. et al. : J. B. J. S., 47-A, 1408, 1965.

4) Roger Dee : J. B. J. S., 54-B, 88, 1972.

5) 神中 - 河野: 関節成形術, 日本医書. 昭24.

6) 七川: 整形外科. 20, 246, 1969.

7）前沢ほ加：関東整災誌. 1, 47, 1970.

8）永山ほ加：整形外科. 22, 11101971.

9）松葉ほ加：整形外科. 24，659, 1973.

犋問長崎大学整形 岩崎 勝郎

(1) 術後の可動域は 経年的に 低下していっている が, 術後まもなくの可動域がしだいによくなっていっ た例はないか。

(2) 肘関節授動術の成績判定は術後何年以上たった ものが適当と考えられるか.

\section{解 答整形 緒方 公介}

(1) 退院時の可動域より改善していた 症例は 22 例 中1例もみられなかった。

(2) 全症例 63 例のうち follow up できたのは 22 例で, 予後調査としてはもう少し症例を增やす必要が あると思う。われわれは，術後年以上たったものにつ いて成績を判定したが，できるだけ長期の成績をみる 必要があると思う。

\section{追 加熊本大学整形外科 木村 千仞}

昨年 SICOT で発表した R A 时の Arthroplasty のうち, Hass 変法で Skin interpositionを主と した 155 例の成績では， ROM が $90^{\circ}$ 以上のもの 60 $\%, 70^{\circ}$ 以下は $18.7 \%$ \%でかなり良い結果を得ている. pronation, Supination るょく保たれている. 長い 経過で起てりうる少数の不安定性, 骨吸収をもカバー して余りある人工関節ができ得れば，利用の価値もあ ろうが, 現在のとてろ, 肘では J K膜, 筋膜, 皮フの 何れを Interposition としても成績は良く，今後人 工肘関節を用いるときの指標となれば幸いである。

\section{澌 問} 九大 喜多 正鎮

長崎大の先生に対し

長期成績をみると鳥口突起端の延長が特微的であり 年月を経るにしたがって少しずつ可動性が低下する原 図と考える. 従って長期（20３0年）後の変化をみな がら手術方法を検討する必要がある.

木村先生に対し

鳥口突起端への処置はどのようにしているか，骨切 除が大きければ動摇関節を残す症例があるか.

\section{解 答熊本大学整形外科 木村 千伋}

(1) 症例のながは, 術後長く経て 骨吸収が起て り, 不安定性となったものもあり，ての点が1つの欠 点ともいえる.

(2) 術後 ROMが, 演者のものより良いのは骨切除 部分が少し大きいためではないかと考える. 